\title{
Urban Flood Control in Sringin Catchment, Semarang City, Central Java Province, Indonesia
}

\author{
Ngo Pheaktra \\ Sangkat Tuk Laak III, Khan Tuol Kork, PnomPenh, CAMBODIA \\ ngopheaktra@gmail.com
}

\begin{abstract}
Sringin is the lowland area located in Semarang city which has been vulnerable to rob flooding from the Java Sea along with flood triggered by the intense amount of rainfall. The case study will further discuss the hydrological analysis, transformation of rational method into flow hydrograph with the design rainfall of 25-year return period, and unsteady flow analysis by HEC-RAS 5.0.3 under existing condition and design condition. The result shows that the design rainfall of 25 -year return period measures $173 \mathrm{~mm}$ in vertical length and data collected from the office of public work, Semarang city can be used to implement the design scenario with normalization of drainage system and the increase of levee with the freeboard up to $0.75 \mathrm{~m}$ is proved to be the solution to the flood inundation in that flood-prone area while the flood under existing condition has caused excessive discharge at downstream up to 9 hours.
\end{abstract}

Keyword: Urban flooding; flood routing; flood risk reduction

\section{INTRODUCTION}

Semarang city is an urban area located in the lowland part or coastal area of central Java province, Indonesia. It is one of the flood-prone areas which has been frequently vulnerable to flooding especially in northern part of the city. It has been suffering from floods damage since 1973 due to the climate and topography change following the population growth, the urbanization and industrialization (Harwitasari, 2009). According to the office of Public Work Semarang City, the considerable flooding occurred four times from overflowing rivers as the following year 1973, 1988, 1990, and 1993. For that reason, flood risk reduction and various flood mitigation plans are prioritized topic needed to be done for case study in Srining catchment, Semarang city. Meanwhile, in case of the low-land area of that region, most of the people of the flood-prone area are unable to relocate to higher land, and they don't have willingness to move to another region. They prefer to stay in their current houses instead of moving to another area even if they were aware of detrimental effects of floods which are imminent (Harwitasari, 2009).

Therefore, the problem should be tackled locally. By considering all of the above, the structural countermeasure is one of the most effective flood control methods applied successfully for solving flood inundation in the low-lying area. The study area of this case study was conducted in Sringin catchment located in Semarang city, central Java Indonesia. A total land area is $14.5 \mathrm{~km}^{2}$ and the total population approximately
92,306 people with people density is 3,371 people per square kilometer.

\section{MATERIALS AND METHODS}

Catchment rainfall obtained by using Thiessen polygon Method from three rainfall stations which are Karaingroto station, Pucang Gading station and Simognan station with 20-year data series. The rainfall distribution selected based on Goodness of fit test (the Chi-square test).

The river geometric data are received from the office of public work Semarang city as secondary data and assumption from base map done by ArcGIS and Google earth pro.

Table 1. Rainfall data series available at Simongan, Pucang Gading, and Karangroto station

\begin{tabular}{ll}
\hline Rainfall station & Data series \\
\hline Simongan station & $1991-2011$ \\
Pucang Gading station & $1995-2011$ \\
Karangroto station & $1991-2011$ \\
\hline
\end{tabular}

\subsection{Thiessen Polygon Method}

Catchment rainfall is usually recorded by rain gauge stations which are the point sampling of the catchment storm. To calculate the rainfall of watershed that has a lot of rainfall stations (more than one), several methods can be used, such as Arithmetic mean, Thiessen polygon and Isohyet (Fiedler, 2003). 
In this case study, the Thiessen polygon method has been used to determine the average rainfall over a Sringin area with three rainfall station: Pucang Gading, Simongan and Karangroto station with 20-year data series (1991-2011). The Thiessen polygon method is shown in the following Equation:

$$
P_{\text {ave }}=\sum_{i=1}^{n} \alpha_{i} P_{i}
$$

where $P_{\text {ave }}$ is an average of watershed rainfall $(\mathrm{mm}), P_{i}$ is rainfall depth at each station, $\alpha_{i}$ is the weight of station $i$.

\subsection{Frequency Analysis}

Frequency analysis is one of the methods to determine rainfall or discharge design with certain return period, not only from rainfall data but also discharge which is based on statistic characteristics (Chow, 1988). It is the statistical method which applies to time series data is common practice to fit those data to the theoretical probability distributions. It uses cumulative distribution function of the selected probability distribution to predict magnitude of hydrology event. Additionally, the frequency analysis defines the design values based on the magnitude of hydrologic event having particular probability of occurrence.

There are four alternative approaches to be used to determine the rainfall depth design such as Normal distribution, Log-Normal distribution, Gumbel distribution and Log Pearson III distribution. The most appropriate type of distribution was determined by comparing parameters such statistics standard deviation, the coefficient of variation, asymmetry (skewness) and kurtosis. The theoretical distributions were tested by the given Goodness of fit test. SmirnovKolmogorov test (Lilliefors, 1967).

$$
\Delta_{\max }=\max \mid \operatorname{prob}(Y<y)-\operatorname{Pr} o b(Y<y)
$$

It is rejected if $\Delta_{\max }<D_{c}$ while $D_{c}$ is critical value according to the Smirnov-Kolmogorov table.

Chi-square test:

$$
\chi^{2}=\sum_{i=1}^{k}\left[\frac{(E-O)^{2}}{E}\right]
$$

where $\chi^{2}$ is Chi-squared value, $E$ is the expected relative frequency according to the distribution being tested, in $i^{\text {th }}$ class interval, $O$ is observed relative frequency in $i^{\text {th }}$ class interval, $K$ is the number of class interval.

\subsection{Intensity-Duration-Frequency}

For the Rational method analysis, rainfall intensity must be determined from an event with a duration equivalent to the time of concentration. Rainfall intensity is calculated using Mononobe formula (Laksana, 2015):

$$
I_{t}^{T}=\left(\frac{R_{X}^{T}}{X}\right) \times\left(\frac{X}{t_{c}}\right)^{n}
$$

where: $I$ is rainfall intensity for any duration of $t$ at return period $T$ years (mm/hour), $R_{X}{ }^{T}$ is daily design rainfall at return period $T$ years $(\mathrm{mm}), t_{c}$ is rainfall duration (hour), $n$ is constant (2/3).

\subsection{Rainfall Duration}

The rainfall period chosen for some appropriate techniques should be equivalent to the highest flow discharge for the catchment being examined. For the Rational method, the period used for defining rainfall intensity should correspond to the time of concentration for the water basin. To estimate rainfall period, Australian rainfall-runoff is used as follows (Pilgrim, 1987):

$t_{c}=0.76 A^{0.38}$

where $A$ is the area of watershed $\left(\mathrm{km}^{2}\right)$ and $t_{c}$ is the time of concentration (hour).

\subsection{Modified Rational Method}

Equation for estimating peak flow discharge (flood discharge or design discharge) is the rational equation. And it is among the most useful conventional techniques used to calculate peak discharge at first. The empirical equation of rational method is expressed as follow (Aron \& Kibler, 1990):

$$
Q=K C I A
$$

where $Q$ is the peak discharge $\left(\mathrm{m}^{3} / \mathrm{s}\right), C$ is runoff coefficient, $I$ is the rainfall intensity during time concentration (mm/hour), $A$ is watershed area $\left(\mathrm{km}^{2}\right)$ and $K$ is coefficient which depends on the units used for $Q, I$, and $A$ (K is approximately 0.278 , when $\mathrm{m}^{3} / \mathrm{s}$, $\mathrm{mm} /$ hour, and $\mathrm{km}^{2}$ are used).

In this research, the rational method has been altered to be the flow hydrographs. Basically, there is the drawback found in the rational hydrograph method because this method is likely to exaggerate the rising limb of the hydrograph as the initial surface detention over the watershed is not considered. After the whole catchment develops into tributary to runoff, the rational hydrograph method represents the temporal changes in 
the rainfall distribution. Rainfall distribution are uniformly applied to a small watershed so that the rational hydrograph approach generates a triangular hydrograph as the rainfall period is equivalent to the time of concentration, or a trapezoidal hydrograph while the rainfall period is bigger compared to the time of concentration, as it should be based on the method formulation (Guo, 2001).

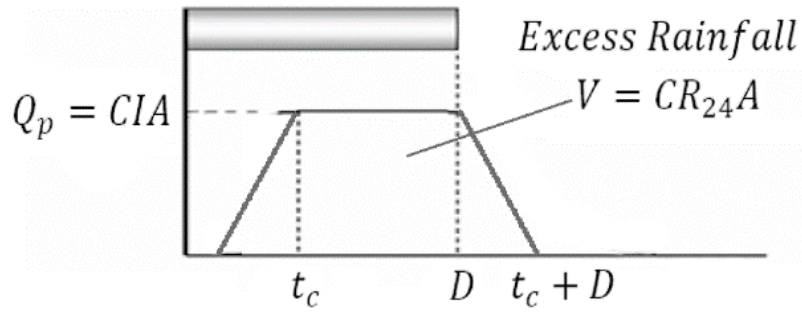

Figure 1. Flow hydrograph from Rational method modification.

Where $C I A$ is the peak flow discharge $\left(\mathrm{m}^{3} / \mathrm{s}\right) C$ is runoff coefficient, $I$ is the rainfall intensity ( $\mathrm{mm} /$ hour), and $A$ is the area of catchment $\left(\mathrm{km}^{2}\right), t_{c}$ is the time of concentration (hour), $\mathrm{V}$ is the volume of excess rainfall $\left(\mathrm{m}^{3}\right), R_{24}$ is the design rainfall $(\mathrm{mm})$ and $D$ is the design storm duration (hour). After the rain stops at $t=D$, the runoff decreases linearly to zero at $t=t_{\mathrm{c}}+D$.

\subsection{Hydraulic Simulation}

Flood routing analysis based on unsteady flow analysis done by HEC-RAS version 5.0.3. There was two scenarios correspondent to the existing condition and the design condition as shown in Figure 2. The first scenario had been running of existing geometry condition of the drainage system of the study area with design rainfall of 25-year return period and tide condition as downstream boundary. The second scenario had been running of normalization geometry condition with the same rainfall and downstream condition.

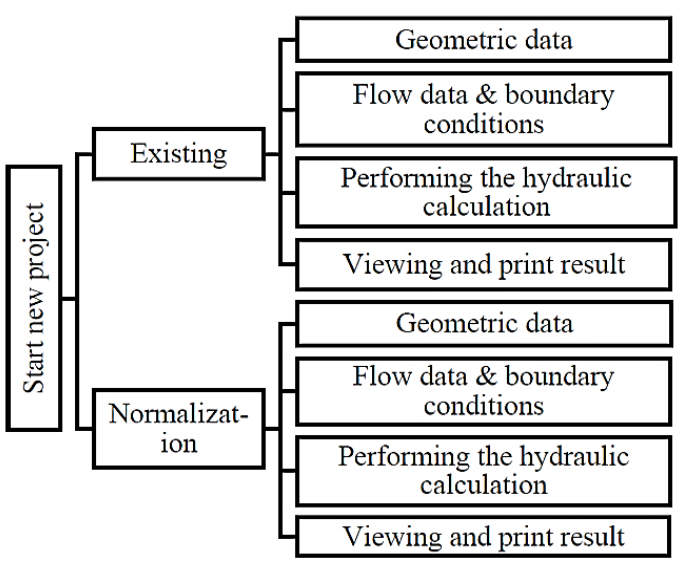

Figure 2. Process of model HEC-RAS.

\subsection{River Geometry of Sringin River}

The secondary data of geometry data were used for simulating the existing condition of Sringin River. The hydraulic structure such as bridges structures were not taken into account of the hydraulic simulation. The hydraulic analysis was conducted by HEC-RAS 5.0.3 with two scenarios, simulation of existing condition and design condition with 25 -year design rainfall.

\subsection{Boundary Condition}

The hydrographs of sub-catchments were distributed as uniform lateral inflow to the drainage system. The lateral inflow of 1, and 3 were applied to upstream flow of Sringin Lama River, and 2 were applied to upstream flow of Sringin Baru River and 4,5 were applied to Kali Sringin river, as indicated in schematic below:

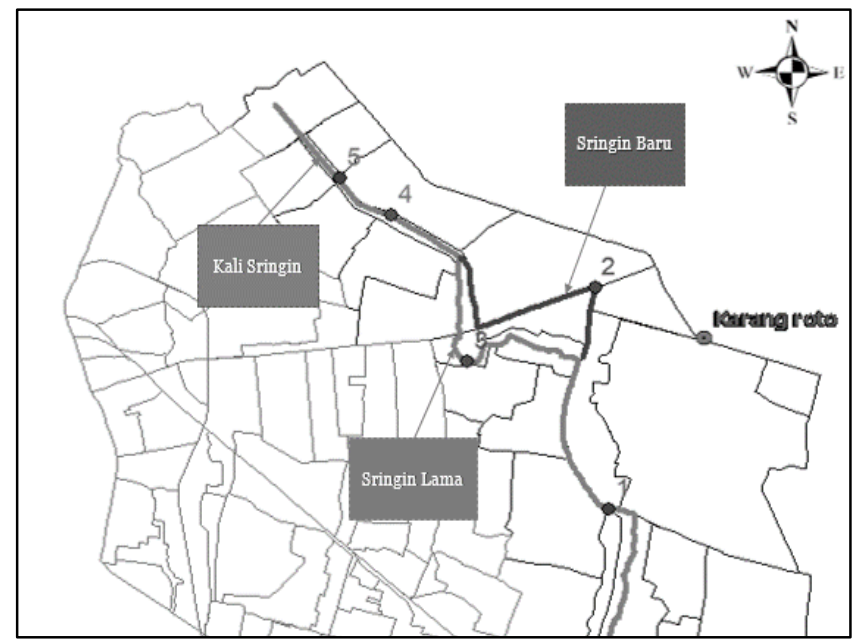

Figure 3. Schematic applied of hydrograph.

\section{RESULT AND DISCUSSION}

\subsection{Rainfall-Runoff Simulation}

There are three rainfall stations considered for collecting rainfall data from Sringin, namely Pucang Gading station, Simongan station, and Karangroto rainfall station. According to Thiessen diagram, the area influenced by Karangroto and Pucang Gading gauge were $1,483.2$ ha with the weight 0.973 and 41.4 ha with weight 0.027 respectively. Because the area affected by Pucang Gading station is too insignificant compared to Karangroto. Therefore, we assume that Karangroto station is the exclusive factor that influences Sringin catchment and Simognan station does not contribute to calculating catchment area rainfall. By applying the Thiessen polygon method (see Figure 4), the maximum daily rainfall received as shown in Table 2. 


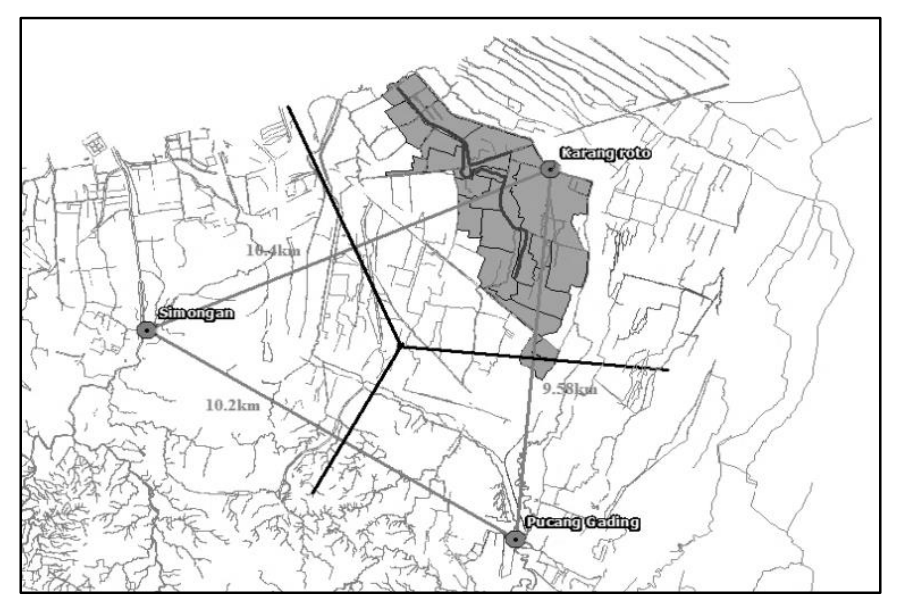

Figure 4. Thiessen polygon of the three rainfall stations.

Table 2. Maximum Daily rainfall

\begin{tabular}{llll}
\hline Year & $\begin{array}{l}\text { Max daily rainfall } \\
(\mathrm{mm})\end{array}$ & Year & $\begin{array}{l}\text { Max daily rainfall } \\
(\mathrm{mm})\end{array}$ \\
\hline 1991 & 81.16 & 2002 & 47.86 \\
1992 & 57.80 & 2003 & 79.19 \\
1993 & 123.08 & 2004 & 138.90 \\
1994 & 46.67 & 2005 & 56.72 \\
1995 & 86.35 & 2006 & 168.33 \\
1996 & 50.37 & 2007 & 99.06 \\
1997 & 78.37 & 2008 & 169.68 \\
1998 & 59.91 & 2009 & 126.92 \\
1999 & 85.82 & 2010 & 123.22 \\
2000 & 115.47 & 2011 & 98.27 \\
2001 & 80.55 & & \\
\hline
\end{tabular}

\subsection{Frequency Analysis}

The frequency analysis of the rainfall data was analyzed by, Gumbel, Log-Normal, Log Pearson Type III, and Normal distribution. The result of the four method distributions had been selected by Goodness of fit test with the confidence level of 0.9 . Results analysis of test as shown in Figure 5 indicated that Log Pearson III distribution was accepted with the design rainfall $173 \mathrm{~mm}$.

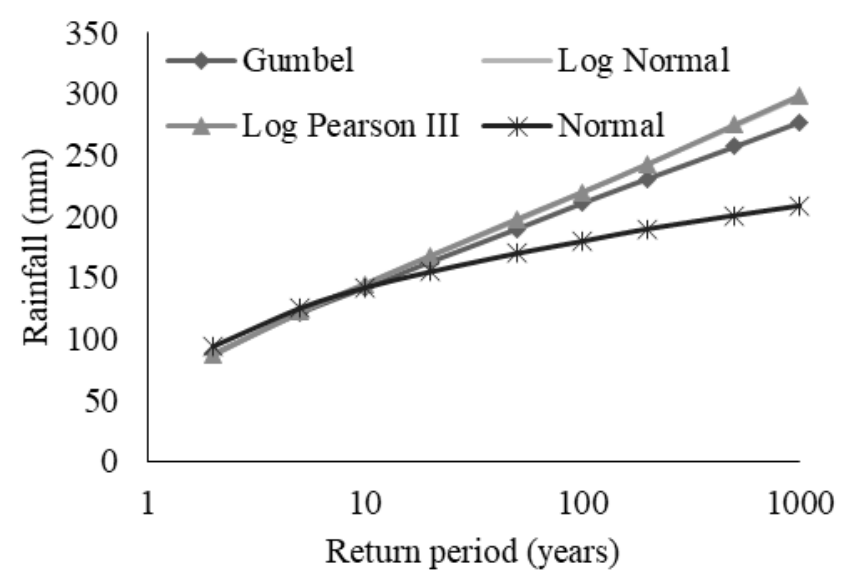

Figure 5. Result of the return period of all methods.

\subsection{Modified Rational Method}

Inflow along Sringin River is assumed as rainfall that uniformly distributed all over the basin. The inflow for this condition can be calculated with rational method. The rational method requires the small catchment equivalent to (less than $300 \mathrm{ha}$ ) and the total area of Sringin Catchment is around $14 \mathrm{~km}^{2}$. Thus, we need to divide basin into several sections. After divide basin into several sections, inflow of each section is presented in Figure 6.

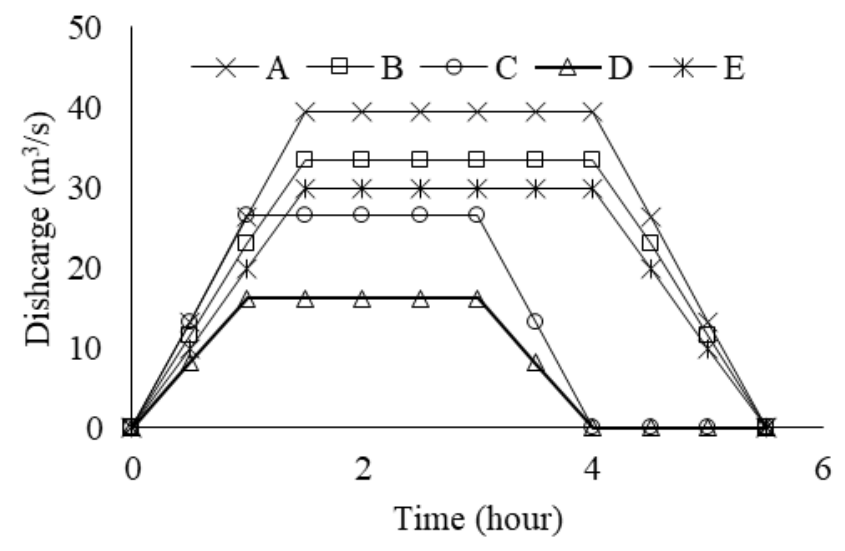

Figure 6. The 25-year Flood hydrograph.

The peak run-off of each sub-catchment varies depending on the run-off area $(A)$ and runoff coefficient (C). From the graph, the maximum discharge varies from $16.19 \mathrm{~m}^{3} / \mathrm{s}$ to $39.35 \mathrm{~m}^{3} / \mathrm{s}$. The peak discharges of subdrainage areas were assigned to estimate the size of cross section of the drainage system along the Sringin Lama and Sringin Baru River. And it does not only assign to determine the capacity of the drainage system, but it is also applied as the flow boundary condition and uniform lateral inflow to compute flood routing in HEC-RAS. Table 3 describes the flow discharge along the Sringin River.

Table 3. Flow hydrograph of Sringin River

\begin{tabular}{llllll}
\hline $\begin{array}{l}\text { Time } \\
\text { (hour) }\end{array}$ & \multicolumn{2}{l}{ Discharge $\left(\mathrm{m}^{3} / \mathrm{s}\right)$} & & & \\
\hline & Area A & Area B & Area C & Area D & Area E \\
\hline 0 & 0 & 0 & 0 & 0 & 0 \\
0.5 & 13.12 & 11.49 & 13.27 & 8.1 & 9.935 \\
1 & 26.23 & 22.97 & 26.54 & 16.19 & 19.87 \\
1.5 & 39.35 & 33.46 & 26.54 & 16.19 & 29.8 \\
2 & 39.35 & 33.46 & 26.54 & 16.19 & 29.8 \\
2.5 & 39.35 & 33.46 & 26.54 & 16.19 & 29.8 \\
3 & 39.35 & 33.46 & 26.54 & 16.19 & 29.8 \\
3.5 & 39.35 & 33.46 & 13.27 & 8.1 & 29.8 \\
4 & 39.35 & 33.46 & 0 & 0 & 29.8 \\
4.5 & 26.23 & 22.97 & 0 & 0 & 19.87 \\
5 & 13.12 & 11.49 & 0 & 0 & 9.935 \\
5.5 & 0 & 0 & 0 & 0 & 0 \\
\hline
\end{tabular}




\subsection{Result of Existing Condition of Sringin Lama}

This result computed with the given existing condition which provides the water surface plotting in Figure 7. The water surface profile was clearly indicated that the overflow occurred almost to upstream of the Sringin Lama River. The description of the inundation duration, the net inflow of the stage and flow hydrograph at the certain cross-section of the drainage system plotted in Figure 8. According to the graph, we can see that the stage of $W S_{\max }$ was +1.17 MLS at 09:00 while the peak flow reached to $69.88 \mathrm{~m}^{3} / \mathrm{s}$. The top bank of this river station was +0.3 MSL. Thus, the overtopping occurred up to $8 \mathrm{~h} 40 \mathrm{mn}$. While the velocity along channel is variously due to variation of bed channel. Maximum velocity is $2.59 \mathrm{~m} / \mathrm{s}$ which occurred at river station 100 .

\subsection{Result of Existing Condition of Sringin Baru}

This result computed with the given existing condition which provides the water surface plotting in Figure 9. The water surface profile of Sringin Baru River has shown that the overflow completely occurred over the Sringin Baru River. The description of the inundation duration, the net inflow of the stage and flow hydrograph at the certain cross-section of the drainage system plotted in Figure 10. From the graph, the stage of $W S_{\max }$ was +1.17 MLS at 09:00 while the peak flow reached to $34.71 \mathrm{~m}^{3} / \mathrm{s}$. The top bank of this river station was +0.27 MSL. Therefore, the overtopping occurred up to $9 \mathrm{~h} 12 \mathrm{mn}$. And the velocity along the channel is variously due to the variation of bed channel. Maximum velocity is $1.39 \mathrm{~m} / \mathrm{s}$ which occurred at river station 838.85 .

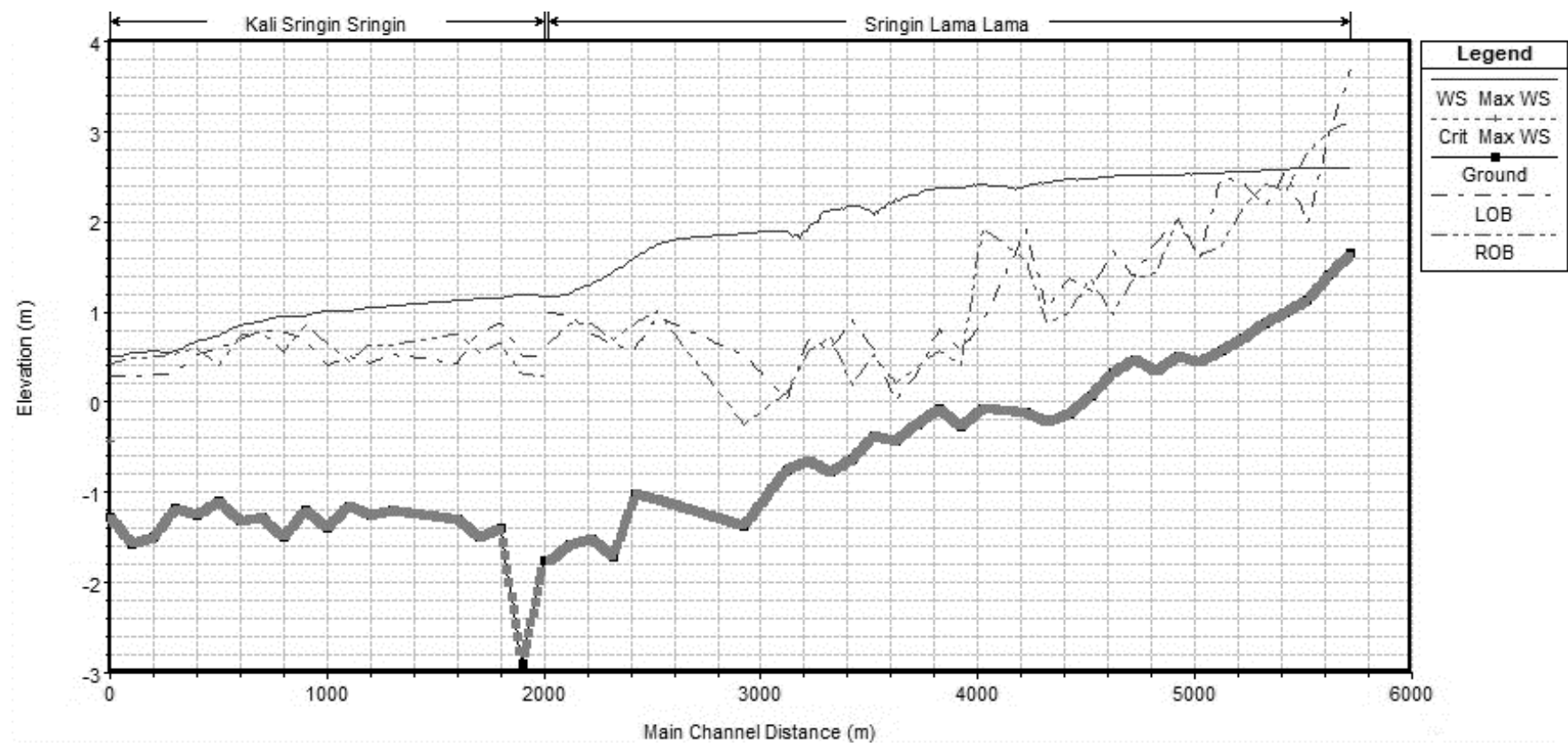

Figure 7. The maximum water surface profile of Sringin Lama River.

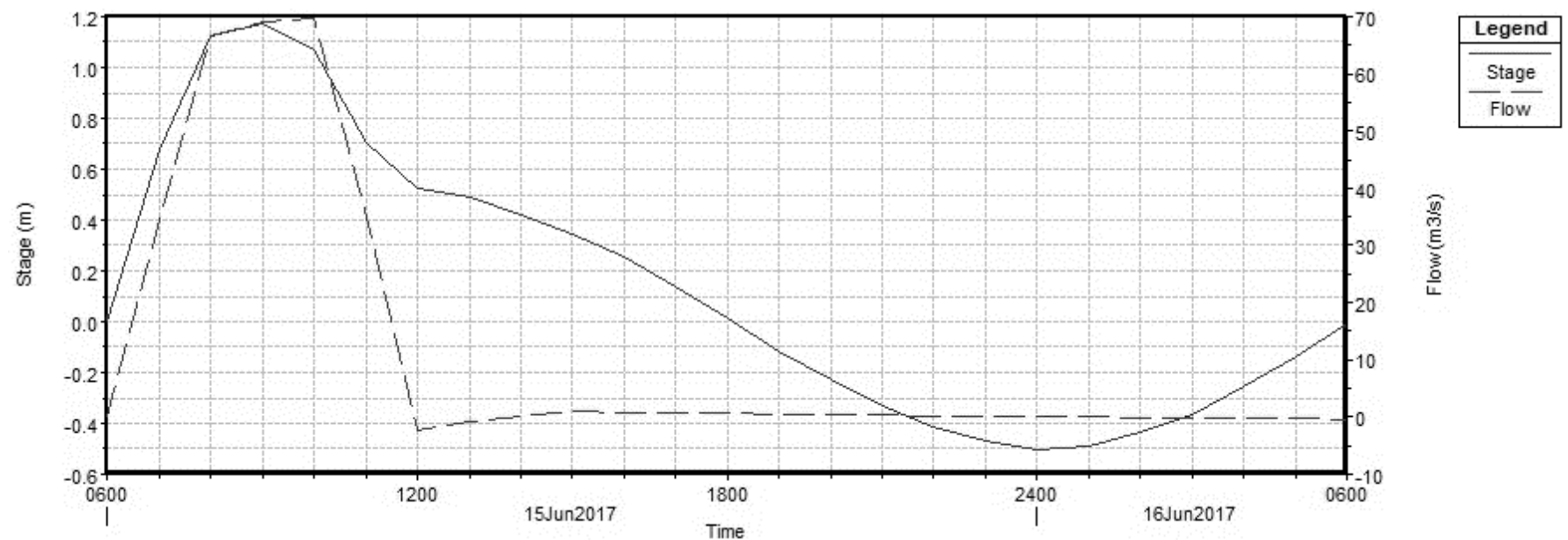

Figure 8. Stage and flow of Sringin Lama River cross section. 


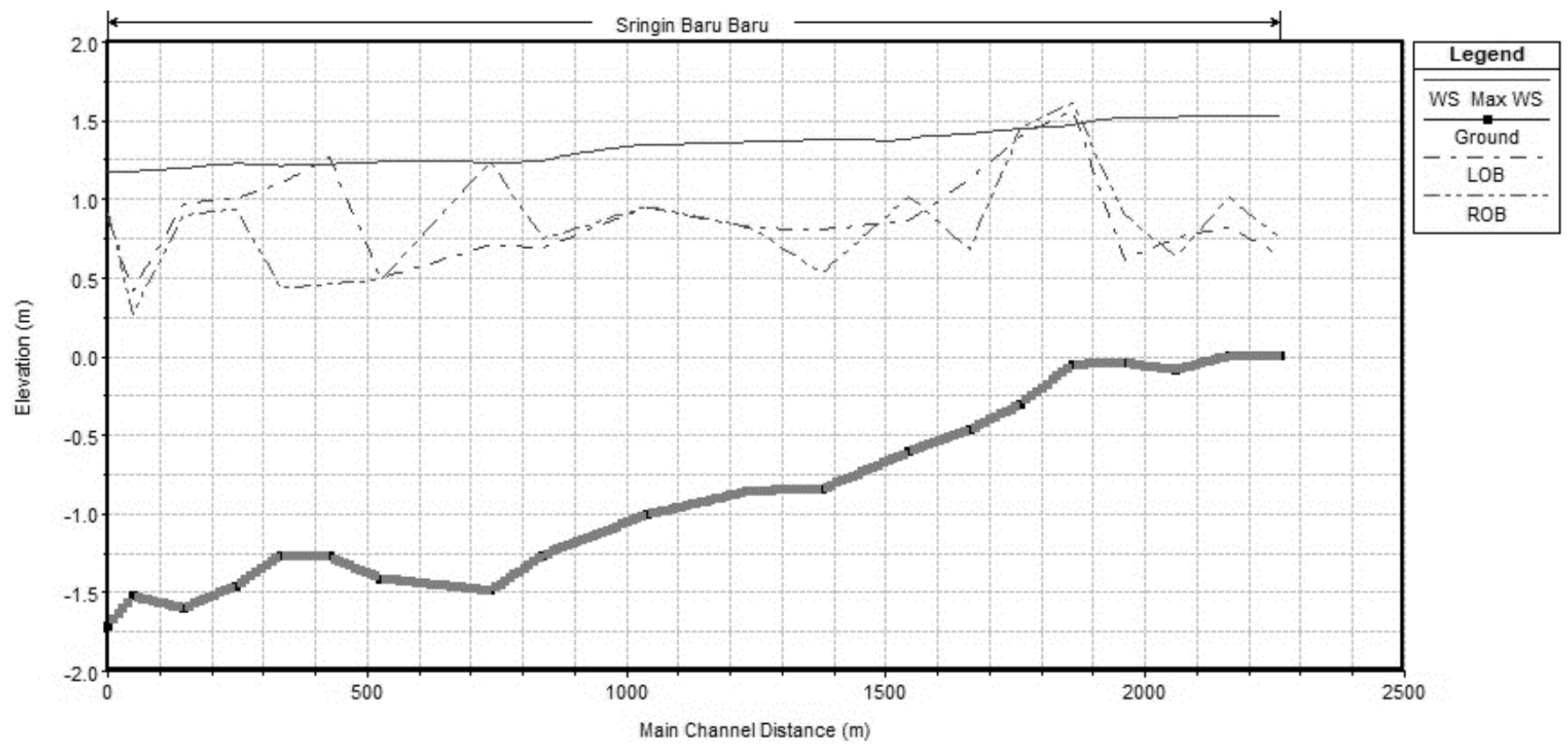

Figure 9. The maximum water surface profile of Sringin Baru River.

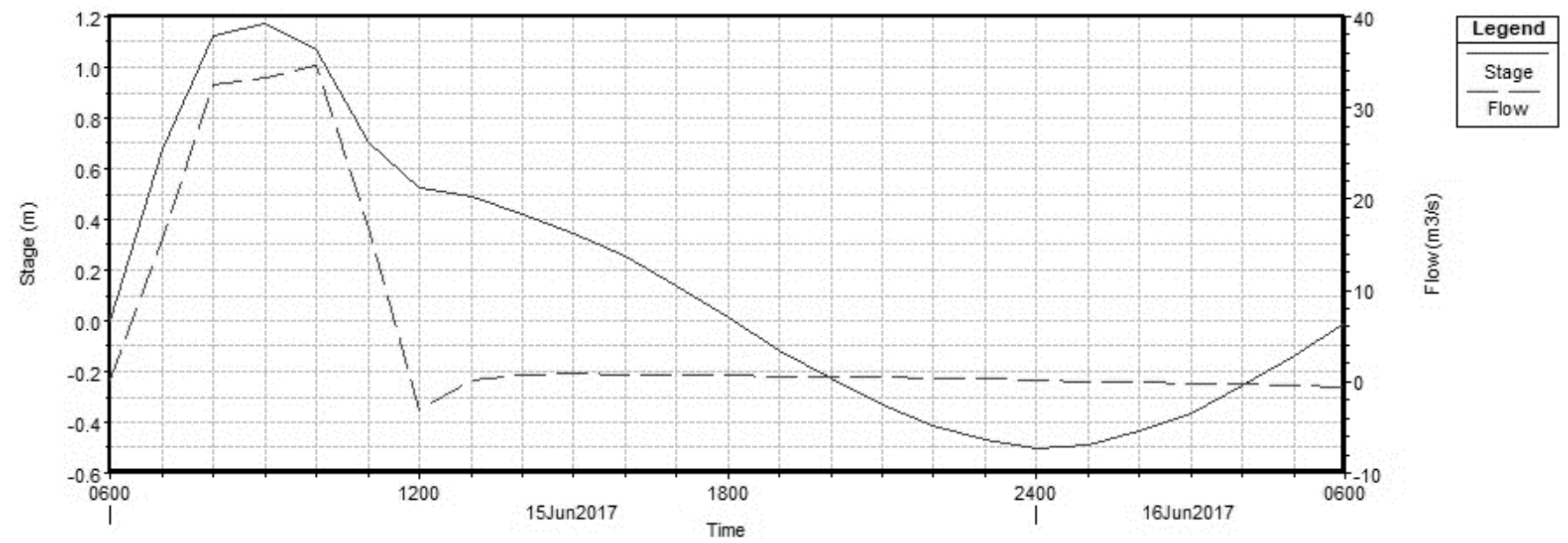

Figure 10. Stage and flow of Sringin Baru River cross-section.

\subsection{Result of design condition}

Under the normalization condition by enlarging the drainage width at upstream and downstream and normalize the riverbed of Sringin Lama and Sringin Baru with slope $0.001,0.0005$ respectively and freeboard $0.75 \mathrm{~m}$ with the 24 hours simulation the given boundary and initial condition show its result in Figure 11 and 12 plotted the maximum water profile which occurred along the Sringin Lama and Sringin
Baru River. As a result, there is no overflow out of the drainage system. So, it means that the drainage capacity is sufficient to solve the 25-year design rainfall supported with the given condition.

Table 4 describes the result of sizing the system drainage cross-section which was done by calculation. All the result was estimated by considering the concrete lining type with the assumption of Manning coefficient $(n=0.012)$. 


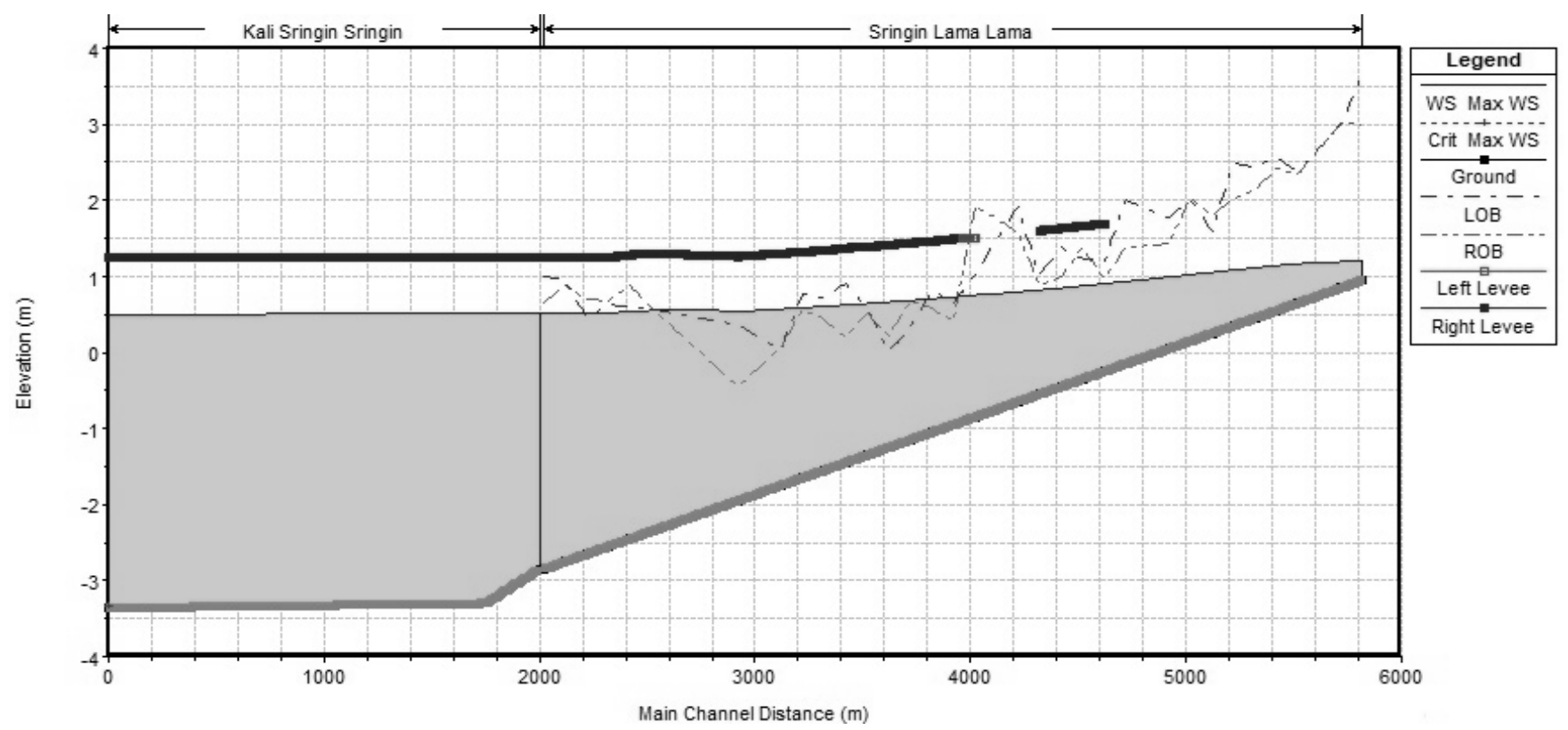

Figure 11. Water profile view of Sringin Lama.

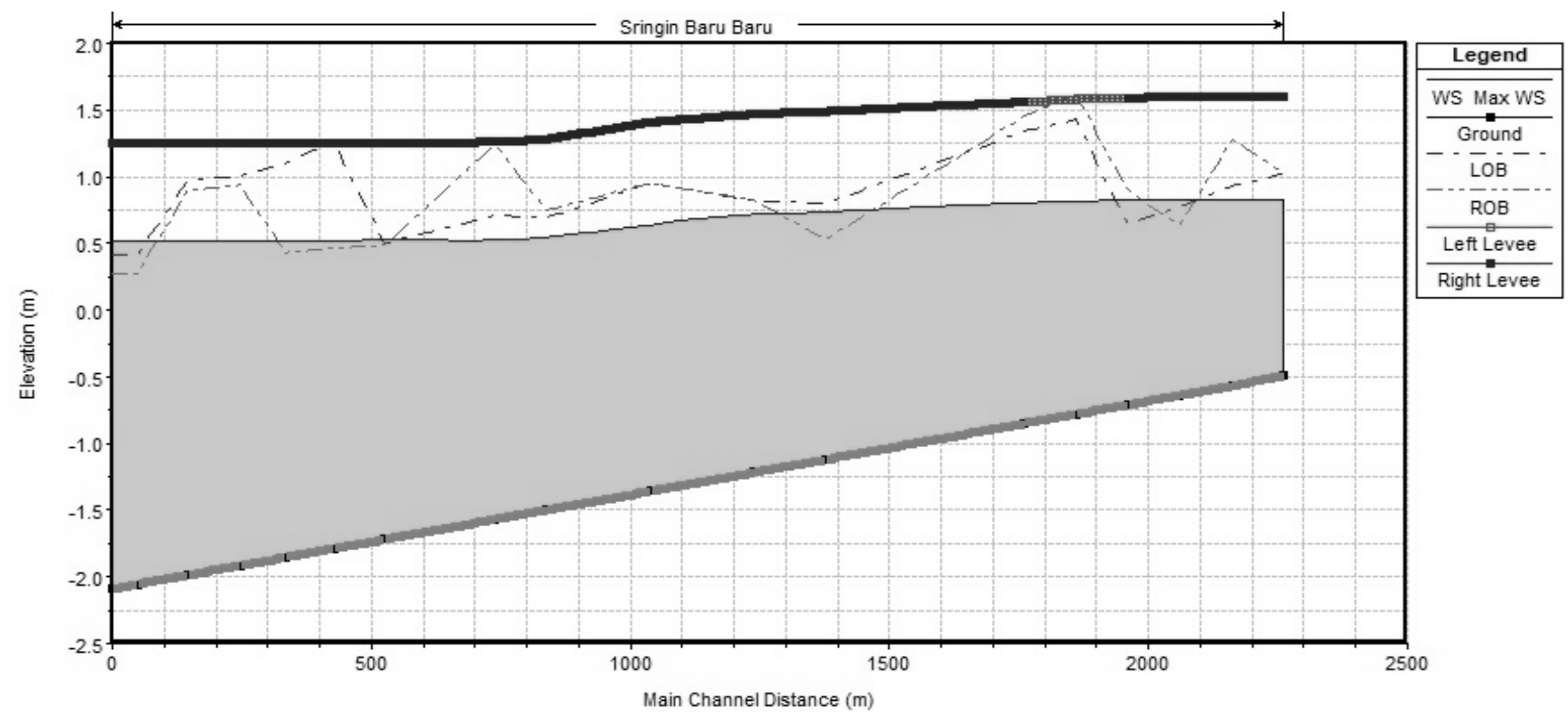

Figure 12. Water profile view of Sringin Baru.

Table 4. Summary result of cross section selection

\begin{tabular}{|c|c|c|c|c|c|c|c|c|}
\hline River & Cross section & $n$ & Slope & Station & $\begin{array}{l}\text { Width } \\
\text { (m) }\end{array}$ & $\begin{array}{l}\text { Free board } \\
\text { (m) }\end{array}$ & $\begin{array}{l}\text { Capacity } \\
\left(\mathrm{m}^{3} / \mathrm{s}\right)\end{array}$ & $\begin{array}{l}V_{\max } \\
(\mathrm{m} / \mathrm{s})\end{array}$ \\
\hline Sringin Lama & Rectangular & 0.012 & 0.001 & $3000-1000$ & 10 & 0.75 & 39.35 & 3 \\
\hline Sringin Lama & Rectangular & 0.012 & 0.001 & $1000-0$ & 20 & 0.75 & 69.17 & 3 \\
\hline Sringin Baru & Rectangular & 0.012 & 0.0005 & $\begin{array}{l}2161.51- \\
738.34\end{array}$ & 8 & 0.75 & 33.46 & 3 \\
\hline Sringin Baru & Rectangular & 0.012 & 0.0005 & 738.34-0 & 14 & 0.75 & 33.46 & 3 \\
\hline
\end{tabular}




\subsection{Discussion current study and the Existing Design}

This section is going to discuss the result of design condition with the current design by the Office of public work, Semarang city 2016 as listed in Table 5.

Table 5. The result of existing design and recent design

\begin{tabular}{|c|c|c|}
\hline Parameter & Existing design & Study propose \\
\hline Design rainfall & 25-year & $\begin{array}{l}\text { 25-year } \\
\text { HEC-RAS }\end{array}$ \\
\hline Model application & Sobek 2.09 .003 & 5.0 .3 \\
\hline Freeboard & $0.8 \mathrm{~m}$ & $0.75 \mathrm{~m}$ \\
\hline $\begin{array}{l}\text { Section of Sringin } \\
\text { Baru }(0-526.27)\end{array}$ & Width $b=30 \mathrm{~m}$ & Width $b=14 \mathrm{~m}$ \\
\hline $\begin{array}{l}\text { Section of Sringin } \\
\text { Baru (638.64- }\end{array}$ & & \\
\hline $\begin{array}{l}\text { 1543.51) } \\
\text { Section of Sringin }\end{array}$ & Width $b=15 \mathrm{~m}$ & Width $b=8 \mathrm{~m}$ \\
\hline Lama $(0-500)$ & Width $b=30 \mathrm{~m}$ & Width $b=20 \mathrm{~m}$ \\
\hline $\begin{array}{l}\text { Section of Sringin } \\
\text { Lama (700-3000) }\end{array}$ & Width $b=12 \mathrm{~m}$ & Width $b=10 \mathrm{~m}$ \\
\hline
\end{tabular}

\section{CONCLUSION AND RECOMMENDATION}

\subsection{Conclusions}

In conclusion, the result simulation of existing condition and design condition with design rainfall 25year return period show that the existing condition causes the inundation to the Sringin Lama and Sringin Baru from 8 hours to 9 hours. While, the design condition with the free board $0.75 \mathrm{~m}$, enlarge the width of drainage up to $10 \mathrm{~m}$ at upstream, $20 \mathrm{~m}$ at downstream and normalize the river bed with slope 0.001 at Sringin Lama and 0.0005 at Sringin Baru along with 25-year design rainfall can solve the flood inundation of extreme rainfall of 25 -year return period. And the concrete lining canal of the drainage system can withstand with the maximum velocity occurred less than $3 \mathrm{~m} / \mathrm{s}$.

The previous study enlarges the canal network up to 12 $\mathrm{m}$ at upstream and $30 \mathrm{~m}$ at downstream with free board $0.8 \mathrm{~m}$. The recent study needs smaller drainage width and shorter levee. The disadvantage of this design is the vast amount of expense and social impact.

The major problems that make both design difference are the boundary condition, the model assumption, and the model application.

\subsection{Recommendation}

For future work, some aspects should be taken into account: a) The more accurate data of land use and contour map with the current condition from surveying at the field are needed to facilitate the rainfall-runoff simulation,

b) Inline structures (bridge) requires sufficient data as the input in HEC-RAS to analyze unsteady flow of the river,

c) The up-to-date rainfall data is required and the data should be adequate for analysis (more than 30 years data series),

d) Due to lack of flow data, calibration of this model cannot be done. It is better to record flow data to make a better hydraulic model.

\section{ACKNOWLEDGMENTS}

I would like to thank AUN/Seed-Net scholarship and Indonesian Government for their financial support during my study.

\section{REFERENCES}

Aron, G. \& Kibler, D. F., 1990. Pond sizing for rational formula hydrographs. Journal of the American Water Resources Association, 26(2), p. 255-258.

Chow, V. T., 1988. Applied Hydrology. USA: McGraw-Hill, Inc.

Fiedler, F. R., 2003. Simple, Practical Method for Determining Station Weights Using Thiessen Polygons and Isohyetal Maps. Journal of Hydrologic Engineering, 8(4), p. 219-221.

Guo, J. C. Y., 2001. Rational Hydrograph Method for Small Urban Watersheds. Journal of Hydrologic Engineering, 6(4), p. 352-356.

Harwitasari, D., 2009. Master's Programme in Urban Adaptation Responses to Tidal Flooding in Semarang, Indonesia. Supervisor: J . A . van Ast.

Laksana, P. J., 2015. Rainfall Characteristic on the Slopes of Mount Merapi Region (Empirical Formula, Duration, Distribution, And Critical Line Woro River). Journal of Civil Engineering Forum, 1(2), p. 43-50.

Lilliefors, H. W., 1967. On the Kolmogorov-Smirnov Test for Normality with Mean and Variance Unknown. Journal of the American Statistical Association, 62(318), pp. 399-402.

Pilgrim, E., 1987. Australian rainfall and runoff. Institution of Engineers, Australia.. 